1,7, 2,1 м/с). Приведены результаты исследований, направленные на совершенствование процесса сушки пивной дробины со стационарным слоем.

Ключевые слова: кинетика, скорость сушки, фильтрационная сушка, влагосодержание, частицы пивной дробины.

Atamanyuk V.M., Terlych A.I., Khalaniya O.M. Filtration Drying of Brewers Grains - Brewing Industry Waste

The article presents the experimental study of the kinetics of filtration drying of brewers grains and curves are obtained concerning changes in moisture content in the brewers grain drying by varying the temperature of the drying agent $\left(45,60,75,90{ }^{\circ} \mathrm{C}\right)$; changes in the moisture content of grains drying by varying the layer's height $(40,80,120,160 \mathrm{~mm})$; changes in moisture content in the brewers grains drying by varying the speed of filtering a drying agent $(0.7,1.14,1.7,2,1 \mathrm{~m} / \mathrm{s})$. The results of the research are aimed at improving the drying proces of brewers grains with the stationary layer.

Keywords: kinetics, the rate of drying, filtration drying, moisture content, particles of brewers grains.

\section{УДК 674.[214+422]}

\section{ДИНАМІКА ФОРМОСТІЙКОСТІ ПОРОЖНИСТИХ КЛЕЄНИХ БРУСІВ}

\section{ДЛЯ СТОЛЯРНИХ ВИРОБІВ}

\section{А.Г. Безкоровайний'}

Охарактеризовано методику проведення експериментального дослідження формостійкості порожнистих клеєних брусів для столярних виробів за умови впливу змінних температурно-вологісних полів упродовж тривалого часу. Проаналізовано показники формостійкості порожнистих клеєних брусів, зокрема їхні відхилення від прямоліформост рійності (у плщй), площинності та паралельності та величину зміни лінійних розмірів за товщиною та порино нормативним вимогам. Це свідчить про придатність використання таких брусів для виготовлення столярних виробів за показниками формостійкості.

Ключові слова: порожнистий клеєний брус, формостійкість, змінні температурно-вологісні поля, кліматична камера, прямолінійність, площинність, паралельність

Постановка проблеми та актуальність досліджень. Позитивні характеристики клеєних брусів для столярних виробів, зокрема екологічність та естетичність, а також їх міцнісні показники, свідчать про перспективність цього конструкційного матеріалу. Однак висока вартість клеєних брусів для столярних виробів $є$ однією з основних причин їхнього обмеженого попиту. Прагнення зменшити вартість клеєних брусів для столярних виробів спонукає їх виробників до пошуку таких дієвих шляхів, реалізація яких забезпечить реальну економічну ефективність. До таких шляхів традиційно відносять зменшення витрат деревини і клейових матеріалів та зменшення енерго- і трудовитрат. Зменшення витрат деревини, як найбільш вагомого показника у собівартості клеєних брусів для столярних виробів, можна досягнути різними технологічними заходами, зокрема використанням нових конструкцій таких брусів - порожнистих клеєних брусів $[1,2]$, у яких замість однієї або кількох ламелей (ділянок) доцільно використати довгомірні рейки (кускові відходи).

пров. інж. А.Г. Безкоровайний - НЛТУ України, м. Львів проф. В.О. Масвський, д-р техн. наук - НЛТУ України, м. Львів; 3 ст. викл. Є.М. Миськів - НЛТУ України, м. Львів
Питання збереження формостійкості порожнистих клеєних брусів для столярних виробів є недостатньо вивченим і вимагає грунтовнішого як теоретичного, так і експериментального дослідження, оскільки наявність порожнини у брусі в окремих випадках може бути причиною порушення його формостійкості.

Об'єкт дослідження - порожнистий клеєний брус з деревини сосни для виготовлення столярних виробів.

Предмет дослідження - формостійкість порожнистого клеєного бруса 3 деревини сосни для виготовлення столярних виробів за умови впливу змінних температурно-вологісних полів впродовж тривалого часу.

Метою роботи $\epsilon$ експериментальне дослідження формостійкості порожнистих клеєних брусів 3 деревини сосни для виготовлення столярних виробів за умови впливу змінних температурно-вологісних полів упродовж тривалого часу.

Методика проведення експериментального дослідження. Для виготовлення експериментальних взірців порожнистих клеєних брусів для столярних виробів використано пиломатеріали та довгомірні рейки (кускові відходи) деревини сосни. Процес виготовлення експериментальних взірців здійснено 3 дотриманням таких основних вимог: деревина без істотних неоднорідностей структури; напрям волокон деревини - радіальний; вологість деревини $10^{ \pm 2} \%$; різниця вологості деревини двох сусідніх ламелей, склеєних між собою, - не більше $1 \%$; температура приміщення, у якому зберігали та виготовляли взірці$20^{ \pm 2}{ }^{\circ} \mathrm{C}$; шорсткість поверхні заготовок під час склеювання - не більше 63 мкм для параметра шорсткості $\mathrm{R}_{\mathrm{m}}$; технологічна витримка після склеювання - не менше 12 год. Для склеювання експериментальних взірців на гладку фугу використано однокомпонентний полівінілацетатний клей фірми Kleiberit марки Klebit 303 (категорія D3 за DIN/EN 204), який відповідає вимогам щодо міцності, тепло- і водостійкості з'єднання та безпечності для здоров'я людини.

Детальний опис технологічного процесу виготовлення експериментальних взірців порожнистих клеєних брусів для столярних виробів наведено у [1].

Активні експериментальні дослідження впливу змінних температурно-вологісних полів на формостійкість порожнистих клеєних брусів для столярних виробів проводили упродовж місяця. Для виявлення динаміки зміни формостійкості порожнистих клеєних брусів здійснили контрольні заміри перед початком активних експериментальних досліджень, у ході їх виконання та через рік після їх завершення. Під час експерименту за допомогою спеціально розробленої кліматичної камери створювали такі умови, які відповідають умовам кухонної кімнати. Кожного дня циклічно змінювали температуру і відносну вологість повітря до потрібного значення. При цьому враховано, що під час приготування їжі впродовж у середньому 4...5-ти годин на добу, спостерігається зміна температури повітря від 18 до $25^{\circ} \mathrm{C}$ і відносної вологості повітря від 50 до $90 \%$, які негативно впливають на деревину і можуть спричинити ії розбухання та всихання, а як наслідок, деформацію порожнистих клеєних брусів.

Кліматична камера (рис. 1) складається із корпусу, виготовленого з полівінілхлоридної плити товщиною 5 мм. У корпусі камери для забезпечення заданої відносної вологості середовища встановлено зволожувач повітря Elbee 
24707, а для забезпечення заданої температури середовища - джерело температури (ТЕН). Рівномірність параметрів середовища забезпечували вентилятором. Автоматичний контроль і регулювання відносної вологості та температури середовища в камері здійснювали за допомогою регулятора температури та вологості РТ-0102 і відповідних давачів.

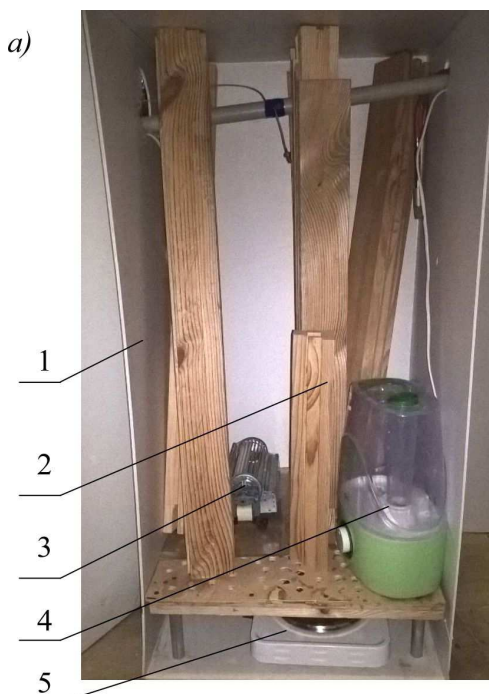

б)

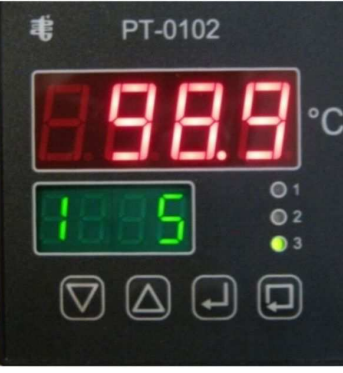

в)

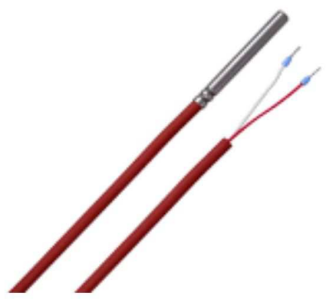

Рис. 1. Світлини кліматичної камери та їі окремих елементів: а) загальний вигляд кліматичної камери (з відкритою передньою дверкою): 1) корпус 2) експериментальний взірець; 3) вентилятор; 4) зволожувач повітря;

5) нагрівальний елемент (ТЕН); б) регулятор температури та вологості

$$
\text { РТ-0102; в) давачі вологості та температури }
$$

Для дослідження динаміки зміни формостійкості порожнистих клеєних брусів виготовлено 20 експериментальних взірців розміром $69 \times 81 \times 400 \mathrm{Mм}$ (ШхТ×Д), з них: 15 - брусків бокових (верхніх) віконної коробки та 5 - брусків нижніх віконної коробки (рис. 2). Для посилення впливу змінних температурновологісних полів на експериментальні взірці порожнистих клеєних брусів їх поверхні не опоряджували.

Формостійкість порожнистих клеєних брусів характеризували такими показниками: відхиленнями форми (відхиленням від прямолінійності у площині відхиленням від площинності); відхиленням розташування (відхиленням від паралельності площин). Отримані результати відхилення опрацьовували за стандартизованою методикою та порівнювали з відповідними допусками, заданими в нормативній документації [3-7], а після цього робили висновок про відповідність встановленим вимогам. Ступінь точності допусків форми і розташування поверхонь прийнято 13 - відповідно до [3]. Шорсткість поверхні не враховували у відхиленнях форми і розташування, оскільки, з одного боку, це не суперечить вимогам чинних нормативних документів, а $з$ іншого - діаметр кінцевика штока (3,5 мм) вимірювального інструмента (цифрового індикатора) не давав такої змоги.
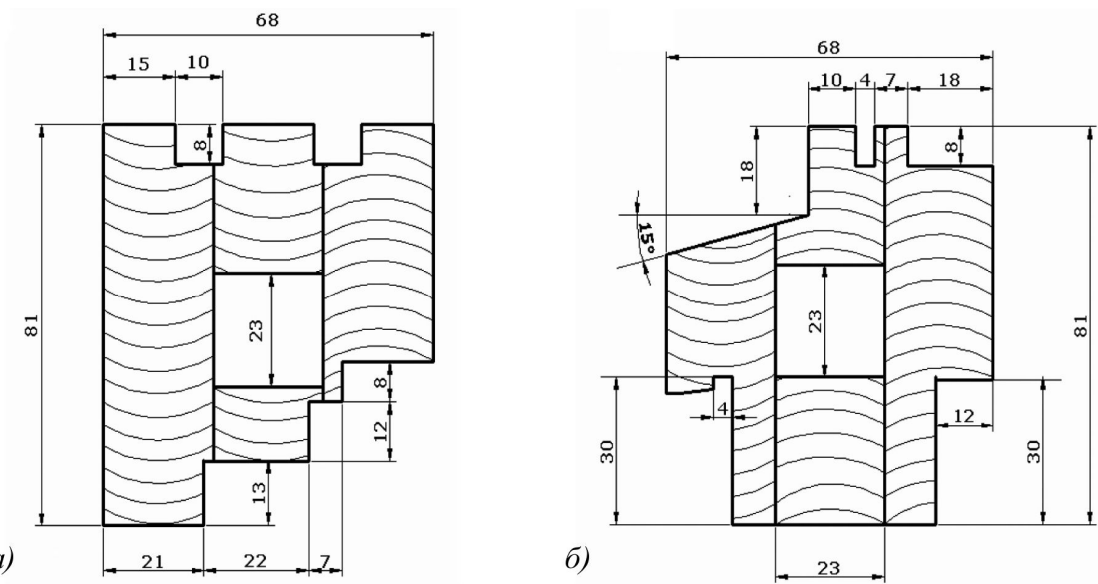

Рис. 2. Загальний вигляд поперечного торця експериментальних взірців порожнистих клеєних брусів для столярних виробів: а) брусок боковий (верхній) віконної коробки; б) брусок нижній віконної коробки

Вимірювання відхилень форми і розташування у порожнистих клеєних брусах здійснювали цифровим індикатором ТИП ИЧЦ (3)-25 фірми Мікротех, а результати вимірювань записували за допомогою спеціалізованого програмного забезпечення ТИП УИС-Р1-СОМ. Взірці порожнистих клеєних брусів нерухомо закріплювали на столі спеціалізованої установки з ЧПК (розробленій на кафедрі АКІТ НЛТУ України), який програмовано переміщували вздовж довжини взірця і водночас автоматично знімали та записували результати вимірювань 3 нерухомо закріпленого над столом цифрового індикатора.

Контрольні заміри товщини i ширини порожнистих клеєних брусів здійснювали за допомогою електронного штангенциркуля ШЦЦ-1-300-0,01143 фірми Мікротех у трьох точках - на відстані не менше 50 мм від двох торців та посередині. Загальний вигляд спеціалізованої установки з ЧПК у процесі вимірювання відхилення від прямолінійності (у площині) порожнистого клеєного бруса № 8 наведено на рис. 3, а схему для вимірювання відхилень форми і розташування у порожнистих клеєних брусах - на рис. 4.

Результати експериментальних досліджень та їх аналіз. 3 метою коректного аналізу результатів дослідження формостійкості порожнистих клеєних брусів здійснено їх графічну інтерпретацію, зокрема, як приклад, на рис. 5 наведено зображення відхилення від прямолінійності (у площині) порожнистого клеєного бруса № 8 (лінія 10) на різних етапах експериментальних досліджень. Як базовий елемент для оцінювання відхилень форми і розташування використовували площину стола спеціалізованої установки з ЧПК (див. рис. 3), яку вважали відповідно до [6] прилягаючою поверхнею (площиною), від якої визначали відхилення.

3. Технологія та устаткування лісовиробничого комплексу 


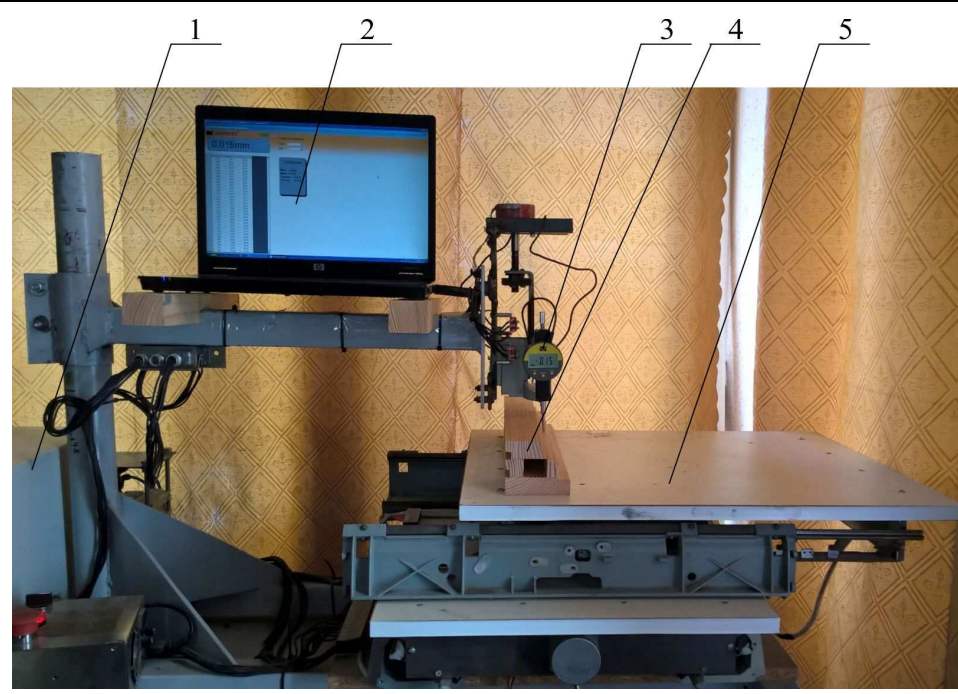

Рис. 3. Загальний вигляд спеціалізованої установки з ЧПК у процесі вимірювання відхилення від прямолінійності (у площині) порожнистого клеєного бруса №8: 1) блок керування установкою; 2) ноутбук із спечіалізованим програмним забезпеченням 3) індикатор иифровий; 4) брусок боковий (верхній) віконної коробки (порожнистий клеєний брус №8); 5) стіл рухомий спечіалізованої установки з ЧПК
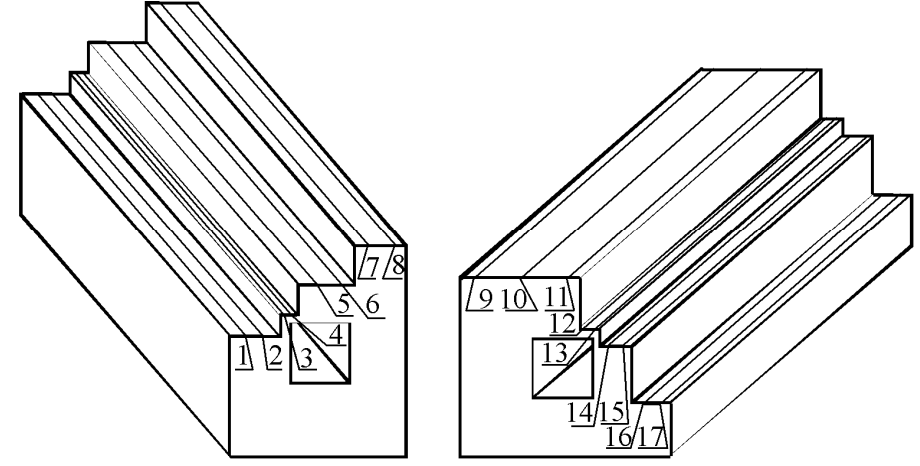

Рис. 4. Схема для вимірювання відхилень форми і розташування у порожнистих клесних брусах (1-17 - лініі вимірювань): а) вигляд бокового (верхнього) бруска віконної коробки; б) вигляд иього ж бруска, розвернутого на $90^{\circ}$ за годинниковою стрілкою

Результати порівняння фактичного відхилення від прямолінійності (у площині) порожнистих клеєних брусів (для всіх ліній) на різних етапах експериментальних досліджень $(E F L)$ з допустимим значенням $\left(E F L_{\text {доn }}\right)$, яке регламентується нормативними документами, зокрема [3] і для номінальних розмірів від 400 до 630 мм становить 0,5 мм (за 13 ступенем точності), свідчать про відповідність брусів встановленим вимогам.
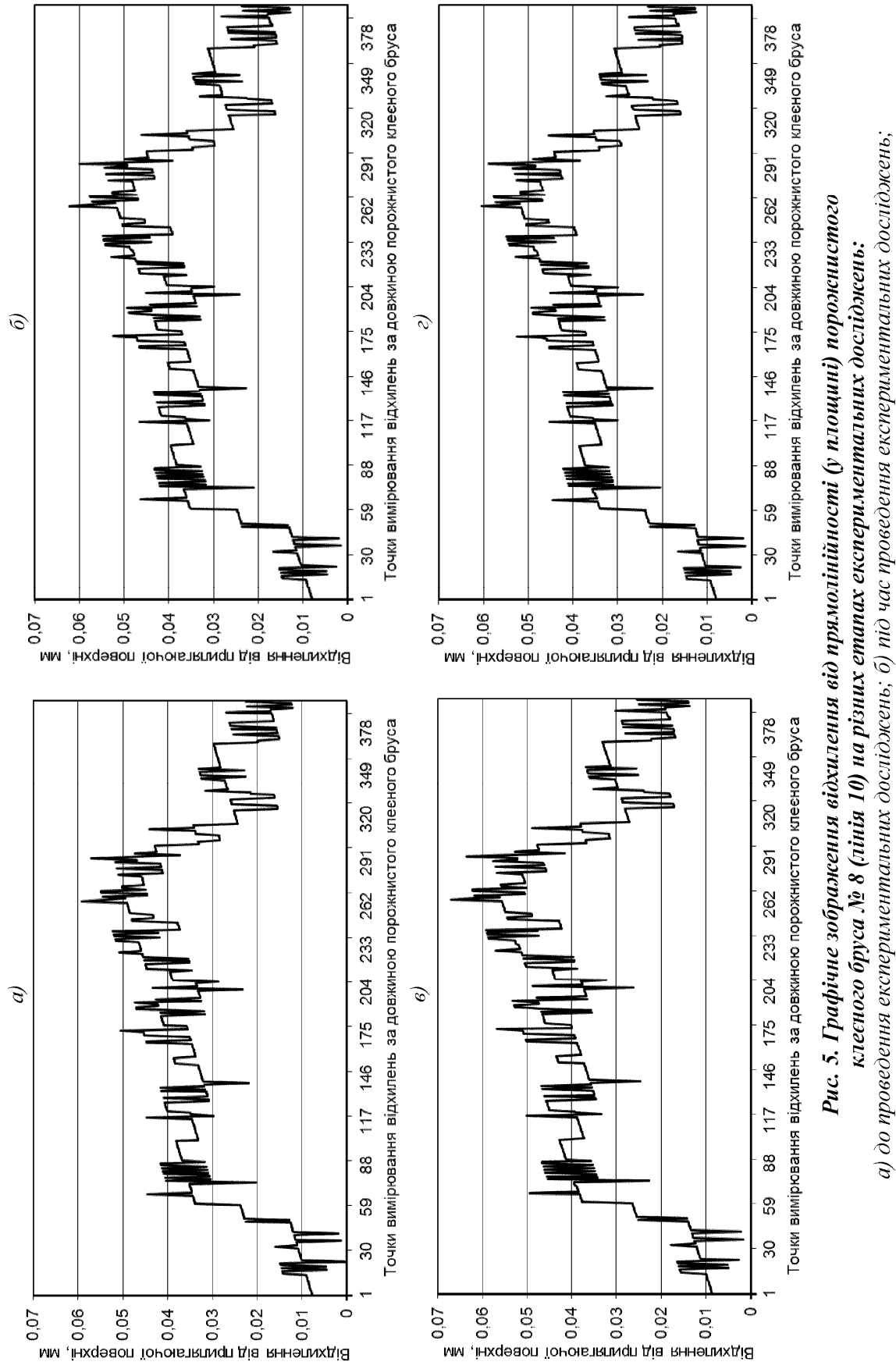
Для прикладу, максимальне відхилення прямолінійності (у площині) порожнистого клеєного бруса (лінія 10) після проведення експериментальних досліджень становило $E F L_{\max }=0,067$ мм (див. рис. 5, в), а до їх проведення -

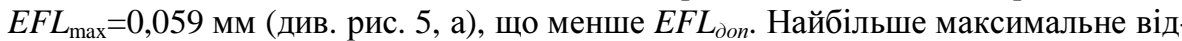
хилення прямолінійності (у площині) порожнистого клеєного бруса становило $E F L_{\max }=0,090$ мм (брус № 14, лінія 7).

Результати порівняння фактичного відхилення від площинності порожнистих клеєних брусів (для всіх ліній) на різних етапах експериментальних досліджень $(E F L)$ з допустимим значенням $\left(E F L_{\partial о n}\right)$, яке регламентується нормативними документами, зокрема [3] і для номінальних розмірів від 400 до 630 мм становить 0,5мм (за 13 ступенем точності), свідчать про відповідність брусів встановленим вимогам. Для прикладу, найбільше максимальне відхилення від площинності порожнистого клеєного бруса становило $E F L_{\max }=0,140$ мм (брус № 14, лінії 7, 8)

Результати порівняння фактичного відхилення від паралельності порожнистих клеєних брусів (для всіх ліній) на різних етапах експериментальних досліджень $(E P A)$ з допустимим значенням $\left(E P A_{\text {доn }}\right)$, яке регламентується нормативними документами, зокрема [3] і для номінальних розмірів від 400 до 630 мм становить 0,8 мм (за 13 ступенем точності), свідчать про відповідність брусів встановленим вимогам. Для прикладу, найбільше максимальне відхилення від площинності порожнистого клеєного бруса становило $E P A_{\max }=0,210$ мм (брус № 14, лінії 7, 8 та 1, 2).

Результати розрахунків величини зміни лінійних розмірів (всихання, розбухання) порожнистих клеєних брусів за товшиною і шириною, отримані на різних етапах експериментальних досліджень, засвідчили, що для усіх брусів величина зміни лінійних розмірів знаходилася у допустимих межах. Граничн відхилення лінійних розмірів порожнистих клеєних брусів для столярних виробів, регламентовані нормативними документами, зокрема [7] і для номінальних розмірів від 30 до 120 мм становлять $\pm 0,15$ мм (за класом точності "точний") тобто для товщини бруса $69^{ \pm 0,15} \mathrm{Mм}$, а для ширини $-81^{ \pm 0,15} \mathrm{Mм}$.

Вплив величини зміни лінійних розмірів порожнистих клеєних брусів, в основному, відображений у результатах їхніх відхилень від прямолінійності (у площині), площинності і паралельності.

Висновок. Результати експериментального дослідження формостійкості порожнистих клеєних брусів засвідчили їх придатність для використання у виробництві столярних виробів, оскільки значення, що характеризують формостійкість брусів, зокрема їхні відхилення від прямолінійності (у площині), площинності і паралельності та величина зміни лінійних розмірів за товщиною шириною, відповідають встановленим нормативним вимогам.

\section{Література}

1. Безкоровайний А.Г. Особливості технології виготовлення пустотілого клеєного бруса / Безкоровайний Андрій Григорович. - Львів : Вид-во НЛТУ України, 2008. - 53 с.

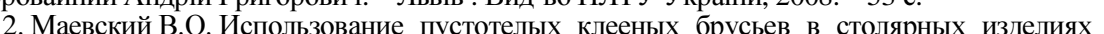
В.О. Маевский В.О. Использование пустотелых клееных брусьев в столярных изделиях В.О. Маевский, В.М. Максымив, А.Г. Безкоровайный // Новейшие достижения в области импортозамещения в химической промышленности и производстве строительных материалов : матер.
3. ГОСТ 6449.3-82. Изделия из древесины и древесных материалов. Допуски формы и расположения поверхностей. - М. : Изд-во Стандартов, 1982. - 7 с.

4. ГОСТ 6449.1-82. Изделия из древесины и древесных материалов. Поля допусков для линейных размеров и посадки. - М. : Изд-во Стандартов, 1982. - 20 с.

5. ДСТУ 2500-94. Основні норми взаємозамінності. Сдина система допусків та посадок. Терміни та визначення. Позначення та загальні норми. - К. : Вид-во Держстандарту України, 1994. $-57 \mathrm{c}$.

6. ГОСТ 24642-81. Основные нормы взаимозаменяемости. Допуски формы и расположения поверхностей. Основные термины и определения. - М. : Изд-во Стандартов, 1982. - 45 с.

7. ГОСТ 6449.5-82. Изделия из древесины и древесных материалов. Неуказанные предельные отклонения и допуски. - М. : Изд-во Стандартов, 1982. - 8 с.

Надійила до редакиії 13.12 .2016 p.

Безкоровайный А.Г., Маевский В.О., Мыскив Е.М. Динамика изменения

формоустойчивости пустотелых клееных брусьев для столярных изделий

Охарактеризирована методика проведения экспериментального исследования формоустойчивости пустотелых клееных брусьев для столярных изделий при условии влияния переменных температурно-влажностных полей в течении длительного времени. Проанализированы показатели формоустойчивости пустотелых клееных брусьев, в частности их отклонения от прямолинейности (в плоскости), плоскостности и параллельности, а также величину изменения линейных размеров по толщине и ширине, и показано, что эти величины соответствуют установленным нормативным условиям. Это свидетельствует о пригодности использования таких брусьев для изготовления столярных изделий по показателям формоустойчивости.

Ключевые слова: пустотелый клееный брус, формоустойчивость, переменные температурно-влажностные поля, климатическая камера, прямолинейность, плоскостность, параллельность

Bezkorovainyi A.H., Mayevskyy V.O., Myskiv Ye.M. Dynamics of Shape Stability Changes in Hollow Glued Laminated Beams Used for Joinery

The method of experimental performing of shape stability of hollow glued laminated beams for joinery under variable temperature and humidity fields for a long time is characterized. The parameters of shape stability of hollow glued laminated beams, e. g. straightness zed. The in pane, deviation of flatness a devition ror in plare dimension change at depth and widh have been analysed. It is shown that hese parameters correspond to established normative regulations. The available data indicates that these beams with appointed shape stability are suitable for joinery production.

Keywords: hollow glued laminated beam, shape stability, variable temperature and humidity fields, climatic chamber, straightness, flatness, parallelism.

\section{УДК 66.047.74}

ДОСЛІДЖЕННЯ ПРОЦЕСУ СУШННЯ ВОДНОЇ ПОЛІМЕРНОЇ

ДИСПЕРСІЇ МЕТОДАМИ НЕІЗОТЕРМІЧНОГО АНАЛІЗУ Р.І. Гаврилів ${ }^{1}$, В.В. Кочубей ${ }^{2}$, С.Р. Філяс ${ }^{3}$, О.В. Сабинін ${ }^{4}$

За допомогою термогравіметричних досліджень проаналізовано процес сушіння водної полімерної дисперсії на основі поліметилметакрилат-полістиролу. Визначено термічну поведінку зразків матеріалу в неізотермічних умовах нагрівання, встановлено механізм сушіння та кінетичні особливості процесу. Результати досліджень на основі те-

доц. Р.І. Гаврилів, канд. техн. наук - НУ "Львівська політехніка";

доц. В.В. Кочубей, канд. хім. наук - НУ "Львівська політехніка";

магістрант С.Р. Філяс- НУ "Львівська політехніка";

магістрант О.В. Сабинін - НУ "Львівська політехніка"

3. Технологія та устаткування лісовиробничого комплексу 